\title{
OPTIMALISASI UMUR BTS, JUMLAH MAINTENANCE SITE CREWDAN PENENTUAN BIAYA MAINTENANCE DENGAN MENGGUNAKAN METODE LIFE CYCLE COST (STUDI KASUS: PT TELKOMSEL INDONESIA)
}

\author{
${ }^{1}$ Alfrianiko Anggriawan, ${ }^{2}$ Rd.Rohmat Saedudin, ${ }^{3}$ Amelia Kurniawati \\ 1,2,3Program Studi Teknik Industri, Fakultas Rekayasa Industri, Telkom University \\ 1alfrianikoanggriawan@yahoo.com, ${ }^{2}$ roja2128@gmail.com, ${ }^{3}$ ameliakurniawati@gmail.com
}

\begin{abstract}
Abstrak-Pertumbuhan jumlah pengguna jasa telekomunikasi di Indonesia meningkat periode 2009-2013. Pada tahun 2013 tercatat jumlah pengguna jasa seluler mencapai 300 juta pelanggan yang melebihi jumlah penduduk Indonesia yang diperkirakan berjumlah 243,6 juta. PT Telkomsel Indonesia merupakan salah satu perusahaan penyedia jasa telekomunikasi yang tercatat memiliki pelanggan sebanyak 131,5 juta dan menguasai sekitar $49 \%$ pangsa pasar jasa telekomuniksai seluler. Salah satu infrastruktur penting dalam mendukung kegiatan operasional operator seluler adalah Base Transceiver Station (BTS). Jika terjadi kerusakan pada BTS yang menyebabkan BTS down, maka akan berakibat hilangnya potential revenue dan hilangnya kepercayaan konsumen. Selain itu penggunaan yang cukup lama juga dapat menyebabkan penuaan BTS dan meningkatnya hazard rate. Oleh karena itu perlu dilakukan analisis umur optimal dari BTS tersebut. Jika BTS mengalami kerusakan akan ditangani oleh maintenance site crew. Jika jumlah site crew banyak akan meningkatkan maintenance cost yang harus dikeluarkan perusahaan, namun jika jumlahnya kurang akan meningkatkan shortage cost. Oleh karena itu juga perlu dilakukan penentuan jumlah maintenance site crew optimal. Metode yang digunakan untuk optimasi tersebut adalah metode life cycle cost. Metode life cycle cost mengkombinasikan umur mesin dan jumlah site crew untuk mendapatkan life cycle cost minimal. Berdasarkan data TTF dan TTR dilakukan plotting distribusi dan penentuan distribusi yang mewakili. Selanjutnya dilakukan pengolahan data sustaining cost dan acquisition cost untuk mendapatkan life cycle cost terkecil. Berdasarkan hasil perhitungan didapatkan life cycle cost terkecil adalah Rp54,467,056,568.00 dengan umur optimal 5 tahun dan jumlah maintenance site crew 5.
\end{abstract}

Kata Kunci : Optimalisasi, Manajemen Perawatan, Life Cycle Cost

\section{Pendahuluan}

PT.Telkomsel Indonesia merupakan salah satu perusahaan penyedia jasa seluler terbesar di Indonesia. Hingga akhir tahun 2013 pelanggan PT.Telkomsel tercatat sebanyak 131,5 juta pelanggan dan meguasai pangsa pasar sekitar $49 \%$ dari total keseluruhan pelanggan jasa telekomunikasi seluler. Jumlah pengguna layanan seluler yang menggunakan jasa Telkomsel cenderung mengalami kenaikan dari tahun ke tahun dan sangat berpotensi untuk terus bertambah. Pertumbuhan jumlah pelanggan ini juga harus diimbangi dengan pembangunan inftastruktur pendukung yang memadai agar operator dapat memberikan pelayanan yang memuaskan. Salah satu infrastruktur penting dalam mendukung kegiatan operasional operator seluler adalah BTS (Base Transceiver Station).

Hingga akhir tahun 2013 PT.Telkomsel tercatat memiliki BTS sebanyak 69.864 unit dimana jumlah ini cukup Mengalami kenaikan yang signifikan dibandingkan tahun-tahun sebelumnya dimana kenaikan tercatat sebesar $29 \%$. Dari semua BTS yang dimiliki, beberapa diantaranya telah berusia rata-rata di atas 10 tahun dengan persentase sebanyak $6.9 \%$ dan berusia 5-10 tahun dengan persentase sebanyak $44.36 \%$.

Dalam sebuah arsitektur jaringan telekomunikasi, BTS memegang peranan yang sangat penting. Jika terjadi kerusakan pada BTS yang menyebabkan BTS menjadi down, maka akan berakibat hilangnya potential revenue dan menyebabkan hilangnya kepercayaan konsumen pada perusahaan. Selain itu penggunaan yang cukup lama juga dapat menyebabkan penuaan BTS dan meningkatnya hazard rate. Oleh karena itu perlu dilakukan analisis umur optimal dari BTS tersebut. Hal ini dapat menghindari terjadinya peningkatan hazard rate yang berhubungan linier dengan penambahan biaya maintenance dan shortage cost. Dengan mengetahui umur optimal BTS dapat mendukung tercapainya cost yang minimal [1].

Jika BTS mengalami kerusakan maka akan ditangani oleh maintenance site crew. Dalam kondisi normal jika jumlah BTS yang mengalami kerusakan sama dengan jumlah maintenance site crew yang tersedia, maka semua kerusakan dapat diatasi dengan segera. Tetapi jika jumlah maintenance site crew tidak memenuhi maka BTS tersebut harus menunggu giliran untuk diperbaiki sehingga akan menyebabkan downtime yang lama. Sementara itu 
penyediaan jumlah maintenance set crew yang banyak juga akan menambah cost, karena dengan banyaknya tim kerja akan meningkatkan biaya overhead serta menambah biaya investasi untuk penambahan perangkat, tetapi kekurangan tim kerja juga dapat meyebabkan biaya menjadi tinggi karena akan menimbulkan downtime yang akan mengurangi profit perusahaan dan kehilangan potential revenue. Oleh karena itu penentuan jumlah maintenance site crew yang optimal sangat dibutuhkan, optimasi jumlah maintenance site crew dilakukan berdasarkan life cycle cost terendah.

Berdasarkan permasalahan yang terdapat pada perusahaan ini, maka akan dilakukan analisis yan berkaitan dengan pendekatan biaya, salah satu metodenya adalah Life Cycle Cost (LCC). Metode LCC merupakan pendekatan total biaya yang dikeluarkan dari awal sampai akhir yang mempertimbangkan beberapa biaya sperti maintenance cost, operating cost, shortage cost, population cost, dan purchasing cost [2]. Dengan metode ini dapat diketahui umur optimal dari BTS serta jumlah maintenance site crew yang optimal yang dapat memberikan masukan kepada perusahaan dalam menentukan kebijakan maintenance-nya.

\section{TINJAUAN PUSTAKA}

\section{A. Life Cycle Cost}

Life cycle cost merupakan penjumlahan perkiraan biaya dari awal hingga penyelesaian, baik peralatan maupun proyek seperti yang ditentukan oleh studi analisis dan perkiraan pengeluaran total yang dialami selama hidup [3].(Blanchard dan Fabricky,1990). Tujuan dari analisis LCC adalah untuk memilih pendekatan biaya yang paling efektif dari serangkaian alternatif sehingga cost term ownership (kepemilikan) yang paling pendek tercapai. Pendekatan Life Cycle Cost menekankan pada pertimbangan total cost selama pengoperasian equipment dari pada initial cost. Model adalah gambaran dari suatu permasalah yang dapat merepresentasikan permasalahan yang sebenarnya. Dalam penelitian ini, permasalahan dimodelkan melalui pendekatan LCC, yang diilustrasikan dalam Gambar 1

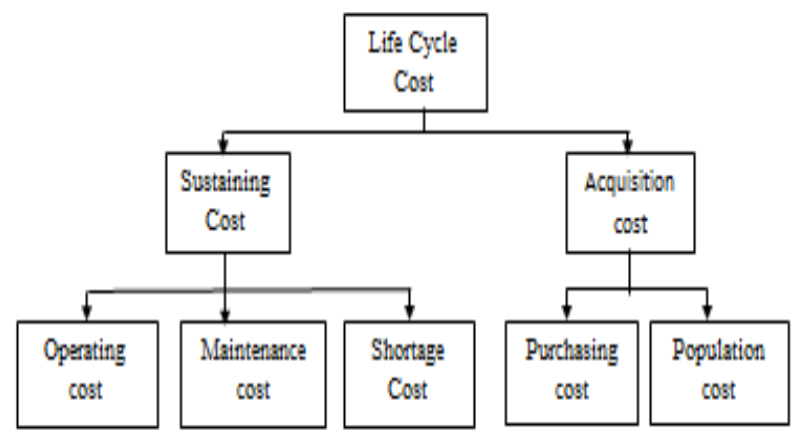

Gambar 1 Model life cycle cost

\section{Sustaining Cost}

Sustaining cost merupakan biaya yang harus dikeluarkan atas kepemilikan suatu perangkat selama periode tertentu. Sustaining cost merupakan penjumlahan dari annual operating cost, annual maintenance cost, dan annual shortage cost.

\section{Operating Cost}

Operating Cost merupakan biaya yang harus dikeluarkan atas beroperasinya suatu alat setiap periodenya 3. Maintenance Cost

Maintenance Cost merupakan biaya yang dikeluarkan untuk perawatan atas equipment itu sendiri secara terus menerus setiap periodenya selama siklus operasi sebuah equipment. Dalam perhitungannya, Maintenance Cost dipengaruhi oleh jumlah maintenance site crew yang disediakan dan besarnya biaya perbaikan equipment tersebut

4. Shortage Cost

Shortage Cost merupakan biaya yang harus dikeluarkan karena terjadinya kekurangan perangkat sebagai akibat dari kekurangan site crew untuk memperbaiki perangkat yang rusak

5. Acquisition Cost

Acquisition Cost merupakan biaya yang dikeluarkan pada pembelian awal sebuah equipment atau sistem. Acquisition Cost merupakan penjumlahan antara biaya yang harus dikeluarkan seluruh perangakat selama hidupnya atau selisih antara biaya pembelian dengan nilai sisa di akhir umur suatu perangkat

\section{Purchasing Cost}

Purchasing Cost merupakan keseluruhan biaya yang dikeluarkan untuk pembelian seluruh perangkat yang diperlukan dalam suatu sistem. Untuk setiap retirement age yang berbeda juga mempunyai annual purchasing cost yang berbeda pula. Pada perhitungan Purchasing Cost harus mempertimbangkan besarnya suku bunga untuk kredit

\section{Population Cost}

Population Cost merupakan biaya yang dikeluarkan setiap periode atas kepemilikan terhadap suatu alat. Population Cost didapatkan dari Annual Equivalent Cost per unit dikali jumlah populasi unit perangkatnya. Equivalent Cost adalah selisih antara Purchasing Cost dengan Book Value.

\section{MEtodologi Penelitian}

Pada penelitian ini dikumpulkan data time to failure dan time to repair dari BTS. Setelah itu dilakukan analisis statistika untuk menentukan parameter distribusi dari data tersebut. Selanjutnya dilakukan uji kesesuaian distribusi dari data tersebut. Setelah itu dilakukan perhitungan untuk memperoleh Mean Time To Failure dan Mean Time To Repair. Model konseptual dari penelitian ini ditampilkan pada Gambar 2.

Optimalisasi Umur BTS, Jumlah Maintenance Site Crew dan Penentuan Biaya Maintenance dengan Menggunakan Metode Life Cycle Cost (Studi Kasus: PT Telkomsel Indonesia) 


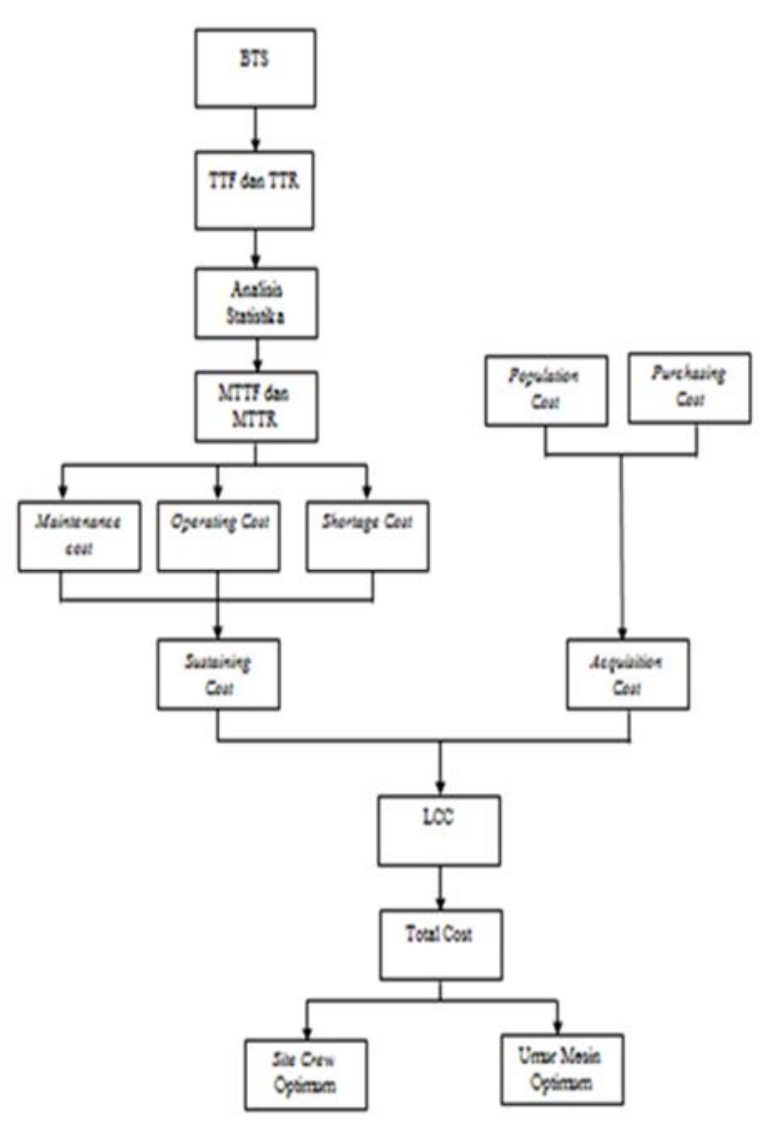

Gambar 2 Model konseptual

Analisis Life Cycle Cost digunakan untuk mendapatkan total cost yang minimum sepanjang siklus hidup BTS. Life Cycle Cost menjumlahkan sustaining cost dengan acquisition cost. Acquisition cost merupakan penjumlahan dari population cost dan purchasing cost. Population cost merupakan biaya yang muncul atas kepemilikan suatu alat. Purchasing cost merupakan biaya yang dikeluarkan untuk membeli atau mengadakan suatu alat. Population cost dan purchasing cost dipengaruhi oleh harga per unit BTS, jumlah BTS, dan umur BTS. Setelah itu dihitung juga sustaining cost yang merupakan penjumlahan dari maintenance cost, operation cost, shortage cost. Maintenance cost merupakan biaya untuk kegiatan maintenance seperti penggantian komponen, biaya tenaga kerja, biaya peralatan. Operation cost merupakan biaya yang dikeluarkan atas beroperasinya suatu alat seperti biaya energi, biaya tenaga operator dan biaya transportasi. Shortage cost merupakan biaya yang muncul karena adanya antrian pada perbaikan alat sehingga menyebabkan loss revenue yang menyebabkan kerugian. Sistematika penyelesaian masalah dari penelitian ini ditampilkan pada Gambar 3 berikut.
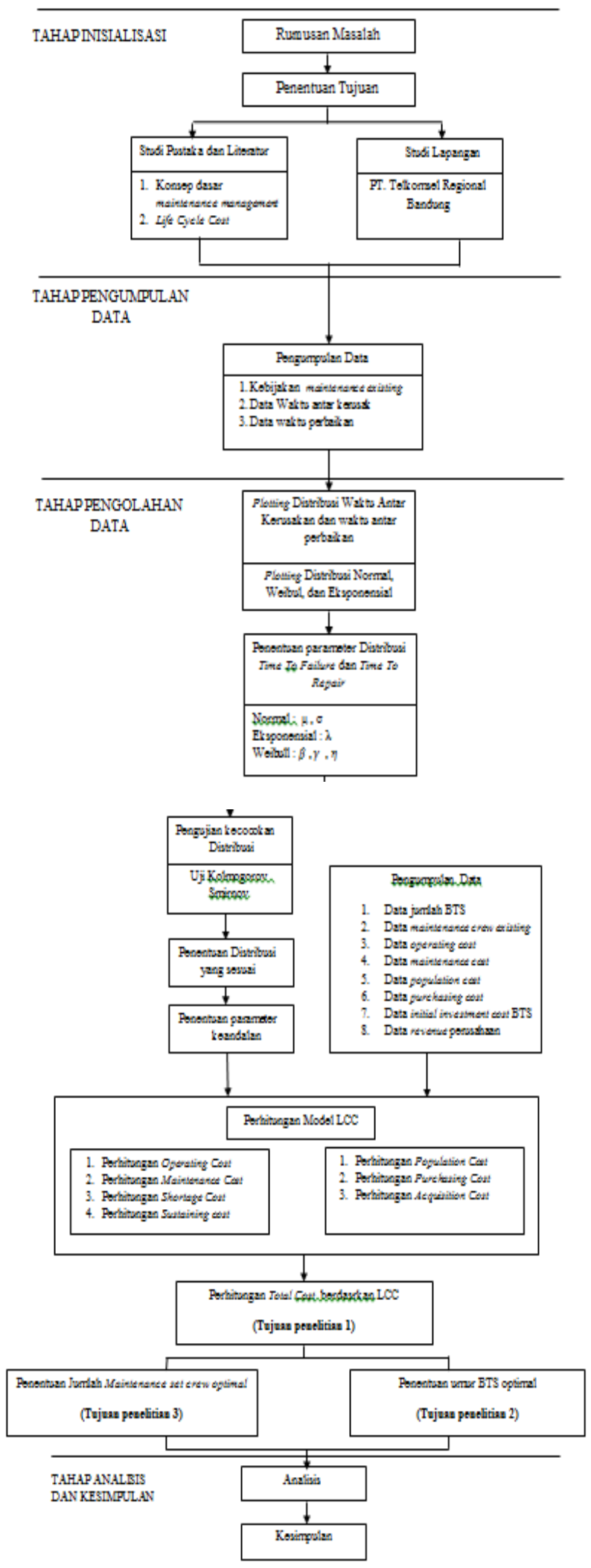

Gambar 3 Sistematika penyelesaian masalah 


\section{HASIL DAN PEMBAHASAN}

Tahapan dalam pengolahan data yang dilakukan untuk mendapatkan output dari penelitian ini adalah sebagai berikut

1. Plotting data time to failure dan time to repair Plotting data dilakukan untuk mendapatkan parameter-parameter dari data tersebut berdasarkan distribusi eksponensial, distribusi normal, dan distribusi weibull.

2. Penentuan Distribusi yang Mewakili

Penentuan distribusi yang mewakili dilakukan terhadap data time to failure dan time to repair dengan menggunakan uji Kolmogorov-Smirnov. Pada uji ini dilakukan pengujian kecocokan distribusi terhadap distribusi eksponensial, normal dan weibull. Hasil dari uji Kolmogorov-smirnov didapatkan distribusi weibull sebagai distribusi yang paling mewakili data TTF dan TTR.

3. Penentuan Parameter Keandalan TTF dan TTR Parameter keandalan TTF dan TTR dapat dihitung setelah memperoleh distribusi yang mewakili dengan parameter masing-masing. Parameter keandalan data TTF dan TTR ditampilkan pada Tabel I dan Tabel II.

TABEL I

\begin{tabular}{|c|c|c|c|c|}
\multicolumn{7}{|c|}{ PERHITUNGAN MTBF } \\
\hline Equipment & $(1 / \beta+1)$ & $\Gamma(1 / \beta+1)$ & $\eta$ & $\begin{array}{c}\text { MTBF } \\
\text { (Hours) }\end{array}$ \\
\hline BTS & 2.88 & 1.7955 & 9.5828 & 17.206 \\
\hline
\end{tabular}

TABEL II

\begin{tabular}{|c|c|c|c|c|}
\multicolumn{5}{|c|}{ PERHITUNGAN MTTR } \\
\hline Equipment & $(1 / \beta+1)$ & $\Gamma(1 / \beta+1)$ & $\eta$ & $\begin{array}{c}\text { MTTR } \\
\text { (Hours) }\end{array}$ \\
\hline BTS & 2.12 & 1.0568 & 0.8181 & 0.865 \\
\hline
\end{tabular}

4. Perhitungan Life Cycle Cost

Total life cycle cost didapatkan dari penjumlahan sustaining cost dan acquisition cost. Sustaining cost merupakan biaya yang dikeluarkan suatu perangkat yang terdiri dari operating cost, maintenance cost, dan shortage cost. Sedangkan acquisition cost terdiri dari population cost dan purchasing cost.

a. Perhitungan Annual Operating Cost

Annual Operating Cost merupakan keseluruhan biaya yang dikeluarkan saat sebuah perangkat beroperasi. Pada pengoperasian BTS operating cost yang dilakukan adalah operating labor cost untuk operator yang menjaga BTS dan energy cost. Perhitungan operating cost ditampilkan pada Tabel III.

b. Perhitungan Annual Maintenance Cost

Annual maintenance cost merupakan biaya yang dikeluarkan untuk aktivitas perawatan peralatan baik memperbaiki ataupun mengganti komponen. Annual maintenance cost dihitung untuk mengetahui besar biaya perawatan setiap tahunnya. Annual maintenance cost terdiri dari maintenance labor cost dan repair cost. Perhitungan annual maintenance cost ditampilkan pada Tabel IV.

TABEL III

PERHITUNGAN OPERATING COST

\begin{tabular}{|c|c|c|c|}
\hline No & Nama Item & Jumlah & Harga \\
\hline 1 & Energy Cost & & $\mathrm{Rp} \mathrm{3,079,296,000.00}$ \\
\hline 2 & Operating Labor Cost & $\begin{array}{l}12 \times 88 \text { orang } \times \text { Rp } \\
700,000,00 . \times 2 \text { shift }\end{array}$ & $\mathrm{Rp} \mathrm{1,478,400,000.00}$ \\
\hline
\end{tabular}

TABEL IV

PERHITUNGAN MAINTENANCE COST

\begin{tabular}{|r|l|l|l|}
\hline No & Nama item & Jumlah & Total cost \\
\hline 1 & Maintenance labor cost & 12 bulan x 1@ Rp 15,000,000 & $R p ~ 180,000,000.00$ \\
\hline 2 & Maintenance cost & Rp 3,436,161,685.56 \\
\hline \multicolumn{2}{|c|}{ Jumlah } & Rp 3,616,161,685.56 \\
\hline
\end{tabular}

Perhitungan diatas merupakan perhitungan untuk jumlah site crew $(\mathrm{M}=1)$ dan retirement age $(\mathrm{n}=1)$.

c. Perhitungan Annual Shortage Cost

Shortage Cost merupakan biaya yang harus dikeluarkan karena kekurangan unit yang disebabkan oleh kurangnya jumlah tim maintenance yang akan memperbaiki perangkat yang rusak. Annual shortage cost dipengaruhi oleh jumlah maintenance site crew dan probabilitas antrian dalam sistem. Contoh perhitungan shortage cost untuk $\mathrm{n}=1$ tahun dan jumlah $\mathrm{M}=1-\mathrm{M}=5$ ditampilkan pada Tabel V.

TABEL V

PERHITUNGAN SHORTAGE COST

\begin{tabular}{|l|r|r|rr|rr|r|rr|}
\hline M & Pr 0,0 & $\begin{array}{r}\text { jumlah } \\
\text { Terjadi } \\
\text { Antrian }\end{array}$ & $\begin{array}{r}\text { Potential Revenue } \\
\text { BTS / Unit/Hari }\end{array}$ & $\begin{array}{r}\text { Annual Shortage } \\
\text { Cost/Unit }\end{array}$ & $\begin{array}{l}\text { Jumlah } \\
\text { Unit } \\
\text { Kurang }\end{array}$ & $\begin{array}{l}\text { Total Annual } \\
\text { Shortage Cost }\end{array}$ \\
\hline 1 & 0.950 & 18.35 & $\mathrm{Rp}$ & $2,094,065.81$ & $\mathrm{Rp}$ & $38,425,486.90$ & 68 & $\mathrm{Rp}$ & $2,617,108,827$ \\
\hline 2 & 0.951 & 17.91 & $\mathrm{Rp}$ & $2,094,065.81$ & $\mathrm{Rp}$ & $37,506,998.99$ & 48 & $\mathrm{Rp}$ & $1,808,487,761$ \\
\hline 3 & 0.951 & 17.90 & $\mathrm{Rp}$ & $2,094,065.81$ & $\mathrm{Rp}$ & $37,476,175.20$ & 28 & $\mathrm{Rp}$ & $1,048,873,296$ \\
\hline 4 & 0.951 & 17.90 & $\mathrm{Rp}$ & $2,094,065.81$ & $\mathrm{Rp}$ & $37,475,594.07$ & 4 & $\mathrm{Rp}$ & $157,143,045$ \\
\hline 5 & 0.951 & 17.90 & $\mathrm{Rp}$ & $2,094,065.81$ & $\mathrm{Rp}$ & $37,475,586.28$ & 5 & $\mathrm{Rp}$ & $185,506,021$ \\
\hline
\end{tabular}

d. Perhitungan Annual Purchasing Cost

Purchasing Cost merupkan total biaya yang dikeluarkan untuk pembelian seluruh perangkat BTS. Pada penelitian ini purchasing cost adalah semua biaya yang dikeluarkan untuk mendirikan sebuah BTS. Annual purchasing cost akan berbeda pada setiap retirement age yang dipengaruhi oleh suku bunga yang berlaki. Perhitungan purchasing cost ditampilkan pada Tabel VI.

e. Perhitungan Book Value

Perhitungan book value dilakukan untuk mengetahui nilai suatu peralatan pada tahun terakhir penggunaannya berdasarkan estimasi tahun perkiraan. Pada perhitungan ini BTS diasumsikan mengalami depresiasi $10 \%$ setiap tahunnya dan estimasi umur adalah 15 tahun. Perhitungan book value ditampilkan pada Tabel VII. 
TABEL VI

PERHITUNGAN PURCHASING COST

\begin{tabular}{|c|c|c|c|c|c|c|}
\hline $\mathrm{N}$ & Harga satuan & $\mathrm{A} / \mathrm{P}, 12 \%, \mathrm{n}$ & Annur & urchasing Cost & Jumlah BTS & Total \\
\hline 1 & $\operatorname{Rp} 1,200,000,000$ & 1.12 & $\mathrm{Rp}$ & $1,344,000,000$ & 88 & Rp 118,272,000,000 \\
\hline 2 & Rp 1,200,000,000 & 0.5916981 & $\mathrm{Rp}$ & $710,037,736$ & 88 & Rp $62,483,320,755$ \\
\hline 3 & Rp 1,200,000,000 & 0.416349 & $\mathrm{Rp}$ & $499,618,777$ & 88 & Rp 43,966,452,347 \\
\hline 4 & Rp 1,200,000,000 & 0.3292344 & $\mathrm{Rp}$ & $395,081,324$ & 88 & $\operatorname{Rp} 34,767,156,474$ \\
\hline 5 & Rp 1,200,000,000 & 0.2774097 & $\mathrm{Rp}$ & $332,891,678$ & 88 & Rp 29,294,467,693 \\
\hline 6 & Rp 1,200,000,000 & 0.2432257 & $\mathrm{Rp}$ & $291,870,862$ & 88 & Rp 25,684,635,866 \\
\hline 7 & Rp 1,200,000,000 & 0.2191177 & $\mathrm{Rp}$ & $262,941,283$ & 88 & Rp 23,138,832,911 \\
\hline 8 & Rp 1,200,000,000 & 0.2013028 & $\mathrm{Rp}$ & $241,563,410$ & 88 & Rp 21,257,580,049 \\
\hline 9 & Rp 1,200,000,000 & 0.1876789 & $\mathrm{Rp}$ & $225,214,667$ & 88 & Rp $19,818,890,654$ \\
\hline 10 & Rp 1,200,000,000 & 0.1769842 & $\mathrm{Rp}$ & $212,380,997$ & 88 & Rp 18,689,527,735 \\
\hline 11 & Rp 1,200,000,000 & 0.1684154 & $\mathrm{Rp}$ & $202,098,485$ & 88 & Rp $17,784,666,694$ \\
\hline 12 & Rp 1,200,000,000 & 0.1614368 & $\mathrm{Rp}$ & $193,724,169$ & 88 & Rp $17,047,726,882$ \\
\hline 13 & Rp 1,200,000,000 & 0.1556772 & $\mathrm{Rp}$ & $186,812,634$ & 88 & Rp $16,439,511,804$ \\
\hline 14 & Rp 1,200,000,000 & 0.1508712 & $\mathrm{Rp}$ & $181,045,495$ & 88 & $\operatorname{Rp} \quad 15,932,003,589$ \\
\hline 15 & Rp 1,200,000,000 & 0.1468242 & $\mathrm{Rp}$ & $176,189,088$ & 88 & $\operatorname{Rp} \quad 15,504,639,707$ \\
\hline
\end{tabular}

TABEL VII

PERHITUNGAN BOOK VALUE

\begin{tabular}{|c|c|c|c|c|}
\hline $\begin{array}{c}\text { Retirement } \\
\text { Age }\end{array}$ & \multicolumn{2}{|c|}{ Salvage Value } & Purchasing Cost & Book Value \\
\hline 1 & & $1,080,000,000$ & Rp $1,200,000,000$ & Rp 1,192,000,000 \\
\hline 2 & & $972,000,000$ & Rp 1,200,000,000 & Rp 1,169,600,000 \\
\hline 3 & $\mathrm{Rp}$ & $874,800,000$ & Rp 1,200,000,000 & Rp 1,134,960,000 \\
\hline 4 & & $787,320,000$ & Rp $1,200,000,000$ & Rp 1,089,952,000 \\
\hline 5 & $\mathrm{Rp}$ & $708,588,000$ & Rp 1,200,000,000 & Rp 1,036,196,000 \\
\hline 6 & & $637,729,200$ & Rp 1,200,000,000 & Rp $975,091,680$ \\
\hline 7 & $\mathrm{Rp}$ & $573,956,280$ & Rp 1,200,000,000 & Rp $907,846,264$ \\
\hline 8 & $\mathrm{Rp}$ & $516,560,652$ & Rp 1,200,000,000 & Rp $835,499,014$ \\
\hline 9 & $\mathrm{Rp}$ & $464,904,587$ & Rp 1,200,000,000 & Rp 758,942,752 \\
\hline 10 & $\mathrm{Rp}$ & $418,414,128$ & Rp $1,200,000,000$ & Rp $\quad 678,942,752$ \\
\hline 11 & $\mathrm{Rp}$ & $376,572,715$ & Rp 1,200,000,000 & Rp $596,153,325$ \\
\hline 12 & $\mathrm{Rp}$ & $338,915,444$ & $\mathrm{Rp} 1,200,000,000$ & Rp $511,132,355$ \\
\hline 13 & $\mathrm{Rp}$ & $305,023,899$ & Rp 1,200,000,000 & Rp $\quad 424,354,046$ \\
\hline 14 & $\mathrm{Rp}$ & $274,521,509$ & Rp 1,200,000,000 & Rp $336,220,075$ \\
\hline 15 & $\mathrm{Rp}$ & $247,069,359$ & Rp 1,200,000,000 & Rp $247,069,359$ \\
\hline
\end{tabular}

f. Perhitungan Annual Population Cost

Population cost adalah biaya yang harus dikeluarkan pada setiap periode atas kepemilikan suatu alat. Population cost diperoleh dari annual equivalent cost per unit dikali jumlah unit perangkat. Equivalen cost diperoleh dengan menghitung selisih purchasing cost dengan book value. Perhitungan population cost ditampilkan pada Tabel VII.

g. Perhitungan Total LCC

Life cycle cost merupakan biaya keseluruhan sistem mulai dari pembelian awal sampai akhir operasinya. Total LCC diperoleh dengan menjumlahkan sustaining cost dan acquisition cost. Perhitungan LCC ditampikan pada Tabel IX.
TABELVIII

PERHITUNGAN POPULATION COST

\begin{tabular}{|c|c|c|c|}
\hline Population & $\begin{array}{c}\text { Retireme- } \\
\text { nt Age }\end{array}$ & $\begin{array}{l}\text { Annual } \\
\text { Equivalent } \\
\text { Cost }\end{array}$ & $\begin{array}{l}\text { Annual Equivalent } \\
\text { Population Cost }\end{array}$ \\
\hline 88 & 1 & $\mathrm{Rp} \quad 8,000,000$ & \begin{tabular}{|ll} 
Rp & $704,000,000$ \\
\end{tabular} \\
\hline 88 & 2 & Rp $30,400,000$ & Rp $2,675,200,000$ \\
\hline 88 & 3 & Rp $65,040,000$ & $\operatorname{Rp} 5,723,520,000$ \\
\hline 88 & 4 & Rp 110,048,000 & Rp $9,684,224,000$ \\
\hline 88 & 5 & Rp163,804,000 & $\operatorname{Rp} 14,414,752,000$ \\
\hline 88 & 6 & Rp224,908,320 & $\operatorname{Rp} 19,791,932,160$ \\
\hline 88 & 7 & Rp292,153,736 & Rp 25,709,528,768 \\
\hline 88 & 8 & Rp364,500,986 & Rp 32,076,086,733 \\
\hline 88 & 9 & Rp441,057,248 & Rp $38,813,037,817$ \\
\hline 88 & 10 & Rp521,057,248 & Rp 45,853,037,817 \\
\hline 88 & 11 & Rp603,846,675 & Rp 53,138,507,439 \\
\hline 88 & 12 & Rp688,867,645 & Rp 60,620,352,758 \\
\hline 88 & 13 & Rp775,645,954 & Rp 68,256,843,939 \\
\hline 88 & 14 & Rp863,779,925 & $\operatorname{Rp} 76,012,633,356$ \\
\hline 88 & 15 & Rp952,930,641 & $\operatorname{Rp} 83,857,896,451$ \\
\hline
\end{tabular}

TABEL IX

PERHITUNGAN LIFE CYCLE COST

\begin{tabular}{|c|c|c|c|c|c|}
\hline \multirow[b]{3}{*}{ n } & \multirow{2}{*}{\multicolumn{5}{|c|}{ Life Cycle Cost }} \\
\hline & & & & & \\
\hline & $\mathrm{M}=1$ & $\mathrm{II}=2$ & $\mathrm{M}=3$ & II $=4$ & $M=5$ \\
\hline 1 & $\operatorname{Rpp} 129,766,966,827$ & $\operatorname{Rep~129,138,345,761}$ & Rpp 128,558,731,296 & Rẹ 127,847,001,045 & $\operatorname{Rp} 128,055,364,021$ \\
\hline 2 & Rp 76,671,190,206 & $\mathrm{Re} \quad 76,028,812,525$ & Rp $75,462,120,724$ & $\mathrm{R} p \quad 74,446,941,807$ & $\operatorname{Rp} 74,622,907,716$ \\
\hline 3 & Rp 61,982,107,708 & Rp 61,322,635,696 & Rp $60,758,149,203$ & $R p \quad 59,609,922,333$ & Rp $59,561,730,446$ \\
\hline 4 & Rp 57,585,891,671 & Rp $56,905,260,294$ & Rp $56,341,892.215$ & $\begin{array}{ll}p & 55,542,598,614\end{array}$ & \begin{tabular}{|l|l|}
4 & $\operatorname{Rp} \quad 54,754,909,741$
\end{tabular} \\
\hline 5 & Rp $57,754,644,740$ & Rẹ 57,047,916,174 & $\operatorname{Rpp} 56,485,371,866$ & Rp $56,208,710,100$ & Rp $54,476,056,568$ \\
\hline 6 & $\operatorname{Rp} 60,507,615985$ & Rp $59,768,808,344$ & Rp $59,206,683,996$ & Rp $58,651,849,037$ & $7 \quad \operatorname{Rp} 56,8$ \\
\hline 7 & $\operatorname{Rp} 64,946,496,785$ & $\operatorname{Rp} \quad 64,168,383,595$ & Rp $63,606,067,124$ & Rp $\quad 63,055,338,973$ & Rp $61.510,289,918$ \\
\hline \multirow[b]{2}{*}{ In } & \multicolumn{5}{|c|}{ Life Cycle Cost } \\
\hline & \multicolumn{2}{|c|}{\begin{tabular}{l|l}
$\mathrm{MI}=1$ & $\mathrm{M}=\mathbf{2}$ \\
\end{tabular}} & $\mathrm{M}=3$ & $\mathrm{II}=4$ & $M=5$ \\
\hline 8 & Rp $70,587,757,853$ & Rp $69,761,634,792$ & Rp $69,198,227,429$ & Rp $68,650,794,354$ & Rp $67,989,186,540$ \\
\hline 9 & Rp $77,138,963,285$ & Rep 76,254,378,928 & Rp $75,688,592,131$ & Rp $75,144,661,557$ & \begin{tabular}{l|l|} 
Rp $74,597,462,609$ \\
\end{tabular} \\
\hline 10 & Rp 84,408,432,452 & Re $83,452,880,381$ & Rp $82,882,898,853$ & Rp $82,342,686,177$ & Rp $81,803,628,437$ \\
\hline 11 & Rp 92,263,521,766 & Rep $91,222,092,601$ & Rp $90,645,392,789$ & Rp $90,109,070,035$ & Rp $89,574,637,049$ \\
\hline 12 & $\operatorname{Rp} 100,609,266,502$ & Rep 99,464,260,465 & Rp $98,877,370,780$ & Rp $98,345,031,289$ & Rp $97,815,556,121$ \\
\hline 13 & Rp $109,376,493,953$ & Re 108,106,997,981 & Rp 107,505. & Rp 106,976,788,983 & Rp 106,4 \\
\hline 14 & Rp 118,514,735,597 & Re $117,096,174,352$ & Rp 116,47 & Rp $115,948,324,050$ & $\operatorname{Rpp} 115,430,104,250$ \\
\hline 15 & Rp 127,987, & Rp 126,391,445,906 & Rp 125,738,311,231 & Rp 125,2 & Rp 124,7 \\
\hline \multicolumn{6}{|c|}{ Life Cycle Cost } \\
\hline $\mathrm{n}$ & $\mathrm{MI}=6$ & $M=7$ & $\mathrm{M}=8$ & $I=9$ & $M=10$ \\
\hline 1 & $\operatorname{Rp} 128,273,125,865$ & Rep 128,490,825,831 & Rp 128,708,465,562 & Rp $128,926,066,43$ & Rp 129,14: \\
\hline 2 & Rp 74,844,439,417 & Re $75,065,971,910$ & Rp $75,287,445,868$ & Rp $75,508,881,682$ & Rp $75,730,291,391$ \\
\hline 3 & Rp 59,787,260,992 & Re $60,013,006,144$ & Rp $60,238,694,749$ & Rp $60,464,345,853$ & $\operatorname{Rp} \quad 60,689,971,227$ \\
\hline 4 & Rp 54,984,029,955 & Re $55,214,401,882$ & Rp $55,444,720,499$ & Rp $55,675,002,211$ & $\begin{array}{lll}R p & 55,905,258,537 \\
\end{array}$ \\
\hline 5 & Rp 54,702,719,736 & Ry $54,938,165,965$ & Rp $\quad 55,173,567,522$ & Rp $55,408,932,739$ & Rp $\quad 55,644,272,894$ \\
\hline 6 & Rp $56,958,028,006$ & Ru $57,199,011,585$ & Rp $57,439,989,229$ & Rp $\quad 57,680,931,114$ & \begin{tabular}{l|l}
$4 p p$ & $57,921,848,242$
\end{tabular} \\
\hline 7 & Rp 60,846,790,604 & Re $61,093,606,156$ & Rp $61,340,695,826$ & Rp $\quad 61,587,750,509$ & Rp $61,834,780,726$ \\
\hline 8 & $\operatorname{Rp} 65,882,581,708$ & $\mathrm{R} \psi \mathbf{0 6 , 1 3 2 , 8 5 5 , 6 3 4}$ & Rp $66,386,637,787$ & Rp $66,640,387,052$ & Rp $\quad 66,894,112,134$ \\
\hline 9 & Rp 71,819,135,551 & Re $\quad 72,018,167,756$ & Rp 72,279,260,257 & Rp $\quad 72,540,334,156$ & 6 Rp $\quad 72,801,384,140$ \\
\hline 10 & Rp 79,422,238,542 & $\mathrm{R} \psi \mathrm{p} \quad 78,551,184,014$ & Rp $78,820,098,635$ & Rp $\quad 79,089,177,821$ & I $\quad$ Rp $79,358,233,460$ \\
\hline 11 & Rp 88,881,269,976 & Re $85,595,176,763$ & Rp $85,868,986,767$ & Rp $86,146,804,130$ & $\operatorname{Rp} \quad 86,424,599,102$ \\
\hline 12 & Rp 97,282,595,220 & Rp 93,161,924,979 & Rp $93,322,628,015$ & Rp $93,609,958,219$ & Rp $93,897,280,976$ \\
\hline 13 & Rp 105,928,760,691 & Rep $103,505,813,417$ & Rp $101,102,943,474$ & Rp 101,400,265,051 & 1. Rp 101,697,960,122. \\
\hline 14 & Rp 114,912,181,756 & Rep 114,331,392,198 & Rp $109,163,586,840$ & Rp 109,457,039,855 & Rp $109,766,007,110$ \\
\hline 15 & $\operatorname{Rpp} 124,193,449,795$ & Re $123,681,230,615$ & $\operatorname{Rp} 118,205,614,202$ & Rp $117,732,763,763$ & Rp $118,053,906,634$ \\
\hline
\end{tabular}


5. Penentuan Site Crew Optimal dan Retirement Age Optimal

Penentuan jumlah tim maintenance optimal dipilih dari total biaya yang terkecil. Berdasarkan perhitungan LCC, maka yang memiliki total biaya terkecil adalah $\mathrm{M}=5$ tim, dengan $\mathrm{n}=5$ tahun, dimana total cost adalah sebesar Rp54,476,056,568.00.

\section{KESIMPULAN}

Dari hasil perhitungan life cycle cost diperoleh hasil yang menunjukantotal life cycle cost paling murah untuk BTS PT Telkomsel tipe platinum regional Jawa Barat adalah Rp54,476,056,568.00. Berdasarkan pada data kerusakan BTS serta biaya-biaya yang diperoleh dalam penelitian ini yang berpengaruh selama pengoperasian BTS, dengan perhitungan menggunakan metode life cycle cost untuk jumlah BTS sebanyak 88 unit diperoleh umur
BTS optimal adalah 5 tahun. Dengan pertimbangan bahwa semua unit BTS berada pada pada umur ( $\mathrm{n}=0$ tahun) pada saat penelitian ini dilakukan. Jumlah optimal dari maintenance site crew BTS adalah 5 maintenance site crew. 1 tim terdiri dari 6 orang yang bekerja pada 2 shift. Kebijakan ini optimal pada saat jumlah BTS yang diteliti berjumlah 88 unit.

\section{DAFTAR PUSTAKA}

[1] Ebeling, Charles. 1997. An Introduction to Reliabilty and Maintainability Engineering. Singapore : The McGraw-Hill Companies Inc.

[2] Barringer.1996.Life Cycle Cost Tutorial. Texas : Marriout Houston Westside.Davis

[3] Blanchard, Fabricky. 1990. System Engineering and Analysis, $2^{\text {nd }}$ ed. Englewood Cliffs : Prentice-Hall 